\title{
Illegal logging, governance effectiveness and carbon dioxide emission in the timber-producing countries of Congo Basin and Asia
}

\author{
Serge Mandiefe Piabuo ${ }^{1,5}$ (Deter A. Minang ${ }^{3} \cdot$ Chupezi Julius Tieguhong $^{2}$. \\ Divine Foundjem-Tita ${ }^{1}$. Frankline Nghobuoche ${ }^{4}$
}

Received: 21 June 2020 / Accepted: 17 January 2021 / Published online: 10 February 2021

(C) The Author(s) 2021

\begin{abstract}
The empirical link between governance and illegal logging is widely accepted amongst scientist, although a minority still purports that illegal logging does not necessarily prevail because of poor governance. However, the nexus linking governance, illegal logging and carbon emission is not well enshrined in scientific literature. This paper seeks to review the literature on illegal logging and governance and empirically investigate the effect of illegal logging and governance effectiveness on carbon emission. Using panel dynamic ordinary least square method on data covering three Congo Basin timber-producing countries and three Asian timber-producing countries, this paper further investigates disaggregated effects between these two groups of countries. The empirical evidence underscores that Congo Basin timber-producing countries are characterised by increasing trend of illegal logging, poor governance effectiveness and corruption. Panel regression reveals a positive and significant impact of illegal logging, governance effectiveness and corruption on carbon emission. Asian producing countries depict a reducing trend in illegal logging and improvements in governance and corruption. There is a positive but not significant impact of illegal logging on carbon emission, and governance effectiveness reduces carbon emission. Thus, the dynamics of governance, illegal logging and carbon emission is not the same between timber-producing countries in Asia and Congo producing counties, thus suggesting the ability of institutions to curb illegal logging and enforce laws to reduce the effects of carbon emission. Multi-stakeholder consultations, government engagement, partnerships and training of control staff can help curb corruption. Legality checks should go beyond having legal documents to effectively check and control of timber concessions and small-scale logging.
\end{abstract}

Serge Mandiefe Piabuo

p.mandiefe@cgiar.org

World Agroforestry Centre, Yaounde, Cameroon

African Development Bank, Abidjan, Côte d'Ivoire

World Agroforestry Centre, Nairobi, Kenya

University of Yaounde I, Yaounde, Cameroon

5 Wageningen University, Wageningen, The Netherlands 
Keywords Illegal logging · Carbon emission · Corruption · Government effectiveness

\section{Background}

Changes in land use account for $20 \%$ of global net anthropogenic carbon emissions, and tropical developing countries account for most of this through deforestation and forest degradation (Denman et al. 2007; Holly and Martin 2007; Schrope 2009; FAO 2016; Cambridge Univ. Press 2014) with timber logging as one of the key agents (Putz et al. 2012). These forests account for $69 \%$ of contemporary and $27 \%$ of historic carbon emissions from the tropics (Putz and Romero 2014; Baccini et al. 2017). Globally, deforestation and forest degradation have reduced by $50 \%$ over the last five years; however, the annual rate of forest loss stands at 7.6 million ha with significant adverse effects on climate and livelihoods (Cambridge Univ. Press 2014). Logging changes the age structure, vertical integration and composition of tree species, thus affecting light, soil, moisture, litter conditions and local temperature (Chaudhary et al. 2016). When the local temperature and soil conditions over large area of land are affected as a result of timber logging, carbon emission becomes more visible and evident (Pearson et al. 2017a). In most parts of the tropics, tropical forests emit more carbon than they can absorb, logging is often illegal and unsustainable (Richardson et al. 2016; Gerwing 2002), and illegal logging can be defined as all logging or related activities which are inconsistent with the law (Gerwing 2006).

Global rates of illegal logging have been reducing; however, they remain alarming among timber-producing countries (SMITH, W. 2002; Guertin 2003). Over 80 million metre cube $\left(\mathrm{m}^{3}\right)$ of illegally logged timber comes from nine timber-producing countries within the tropics (Nabuurs 2018). The negative ecological impact of illegal logging is well enshrined theoretically; its incidence has equally been reported in many studies (Guertin 2003; Nguyen and Cao 2020). Human-induced greenhouse gas emissions from forest clearance and degradation represent $12-20 \%$, of which illegal logging is a significant contributor (Hoare 2015). Illegal logging contributes to loss of biodiversity especially when certain species are highly logged; this has resulted in mahogany and tropical cedar being at risk of extinction in Indonesia (verchenkova et al. 2019; Smith, et al. 2014). The loss or reduction of forest cover is accompanied by subsequent loss of environmental services and carbon sequestration capacity of forests is heavily reduced (Reboredo 2013). About 420 million tons of carbon is lost from the global forest due to harvesting of industrial round wood (Guertin 2003).

Illegal logging has been extensively investigated in developed countries, South America and Asia (Nguyen and Cao 2020; Smith et al. 2014) with focus on illegal trade of timber and related activities (FERN 2013; Carodenuto and Cerruti 2014). Baccini et al. (Puzon et al. 2011) underscore that tropical forests emit more than they can absorb carbon from the atmosphere, thus losing their status as carbon sink. They underlined that the process of removing small portions of trees in parts of the forest cannot be seen through satellite image; however, significant amount of carbon is lost. Most of these trees removed from the forest are done illegally (Nguyen and Cao 2020), thus contributing to significant reduction in carbon sequestration potential of the forest (Baccini et al. 2017). Related studies on the ecological impacts of illegal logging in developing countries are rare especially on how institutional quality and governance affect carbon emission. Nguyen and Cao 2020 and Puzon et al. 2011 investigated domestic governance frameworks for enhancing carbon emission policies but not their impacts on carbon emission. Therefore, this paper sets out 
to meet two key objectives; (1) review literature on illegal logging, governance and carbon emission trends and (2) use time series data to explore the combined effects of illegal logging and governance effectiveness on carbon emission. The significance of this paper is grounded on the fact that this study focuses on timber-producing countries in the Congo Basin and Asia that account for more than $50 \%$ of global illegal logging from primary forest and is made up of a group of countries with governance effectiveness at different levels (Nabuurs 2018). These countries are endowed with forest with high carbon sequestration potential, which if logging is well tracked, they can significantly contribute to reducing negative effects global carbon emission.

\section{Literature review}

The success of forest sector programs and initiatives depends a lot on the ability of governments in tracking and controlling illegal logging. Lima et al. (2018) underscored that the federal and state "undesignated" lands are at risk of loosing $40 \%$ of their total volume of illegal logging in Brazil. Nguyen and Cao (2020) suggest that relying on illegal timber volumes and descriptions to tackle illegal logging may not yield desired outcomes, considering the attributes of loggers, their level of engagement in the activity and motivations and the level of organisation of the crime are key options to tackling illegal logging. The section below reviews the trends of illegal logging, attributes of loggers, motivations and level of organisation of illegal logging, it equally explores the governance framework within which these crimes are perpetuated.

\subsection{Illegal logging}

Logging without permit and rampant abuse of logging permits (logging more than permitted volume, logging below the accepted diameter and logging out of the permitted logging area) features strongly amongst the most prominent types of illegal logging within the Congo Basin (Lindner et al. 2014; Averchenkova 2017). Illegal logging by large-scale concessions is common practice and often characterized by logging without management plans, logging in prohibited areas, over logging, non-payment of fees and taxes (Gerwing 2006; SMITH, W. 2002). EIA (2019) reports that a timber exploiting group in Republic of Congo has illegally obtained over 100000 ha of Labema Forest management unit; over 46 different species have been over harvested accounting for 85000 cubic metres and equivalent to 15000 trees between 2013 and 2016. This results in an average reduction in carbon stocks of $76 \%$ in selectively logged primary forest (Putz et al. 2012).

In most countries within the Congo Basin, small-scale loggers account for domestic and regional supply of timber which is often illegal (Amariei 2005; Lawson 2014). Exports of timber from artisanal logging vary from one country to another, from one period to another and is equally affected by policy, domestic, regional and world market (Wit et al. 2010). In Cameroon, $92 \%$ of illegally logged timber by artisanal loggers was sold domestically in 2009 (DeFries 2002); meanwhile, in DRC artisanal logging was 13 times higher than timber logged legally in 2012, $85 \%$ of the illegally logged artisanal timber was sold in the domestic market (Witness 2015). In Asia, Lee et al. (2018) underscore that illegal logging in Cambodia, Indonesia and Bolivia exceeds $80 \%$.

Artisanal small-scale logging has not, however, been widely documented; this is because these exploiters are the principal actors of the informal sector. The ever-growing informal 
sector is a principal driver of illegal logging within the Congo Basin (Global Witness 2004; Environmental Investigation Agency,Inc. 2019). This sector accounts for 50\%, 70\% and $90 \%$ of annual wood harvest for Cameroon, Ghana and DRC, respectively (DeFries 2002; Witness 2015; Cerutti and Lescuyer 2011; Lescuyer et al. 2014). These small-scale loggers assure timber supply within the national territory of Congo Basin countries and understand how to bypass national controls to market wood products. In the Democratic Republic of Congo (DRC) where small loggers predominate; about 8000 of them are responsible for increasing illegal logging averaging 1.5-2.4 million $\mathrm{m}^{3}$ per year (Marfo 2010). Illegal logging by private individuals is equally rampant within the region accounting for more than $200000 \mathrm{~m}^{3}$ of illegally logged timber in Cameroon (Hoare 2014; Djiré 2003). Artisanal small-scale illegal logging is not only prominent within the Congo Basin; it also occurs rampantly in Brazil, Papua New Guinea (PNG) and Indonesia. Although efforts have been made amongst producer countries to counter illegal logging amongst large concessions, these efforts are often countered by the increasing contribution of artisanal small-scale loggers to total illegally logged timber. Illegal logging increased from 40 to $65 \%$ between 2000 and 2012 in Cameroon, of which chain saw millers accounted for 50\% of the total (WORLD BANK 2002). Table 1 shows a summary of findings from literature review on the extend of illegal logging from artisanal loggers.

Table 1 highlights that artisanal logging is important within the region and in most cases its illegal. This suggests that artisanal logging should be recognised as an important driver of illegal logging and the need for better regulation and control of the sector for sustainable exploitation (Witness 2015).

Forest conversion to agricultural land significantly reduces biological soil properties and forest cover and thus increases carbon emissions (Kishor and Lescuyer 2012). This phenomenon is equally accompanied by loss of ecosystem services which have significant negative effects on biochemical recycling and plant growth (Gan et al. 2016; Gibson et al. 2011). However, forest conversions to agriculture may portray significant negative ecological outcomes but their economic and social benefits cannot be undermined (Edwards et al. 2013). Illegal felling of timber for wood fuel contributes significantly to carbon emission in Africa, representing 30\% of annual emissions (Edwards et al. 2014). Although illegal logging remains high in producing countries, the rate and incidence on carbon emissions are not the same amongst countries and over time, justifying the need for this study.

\subsubsection{Governance}

Corruption within the timber sector can be classified into two: collusive and non-collusive corruption. Non-collusive corruption is when a bribe is asked for a legal activity (obtaining exploitation permit); this increases the cost of the private enterprise or individual (Arias et al. 2013). Collusive corruption is a bribe paid to government officials in order not to pay the penalty that comes with violation of regulation. This bribe does not go to the public treasury but used for personal benefits; both parties benefit from collusive corruption. Logging and transportation of wood within national territories amongst Congo Basin countries by small-scale or artisanal loggers is often done through collusive corruption (Pearson et al. 2017b). Through this corruption mechanism, government officials overlook export or transport without permit, logging outside authorized area and violations of the law in return for bribe. These vested interests serve as insurance to small-scale loggers who pay to avoid the penalty of violation (Smith et al. 2003). Corruption has been reported along all the stages of timber exploitation within Congo Basin and Asian timber-producing 


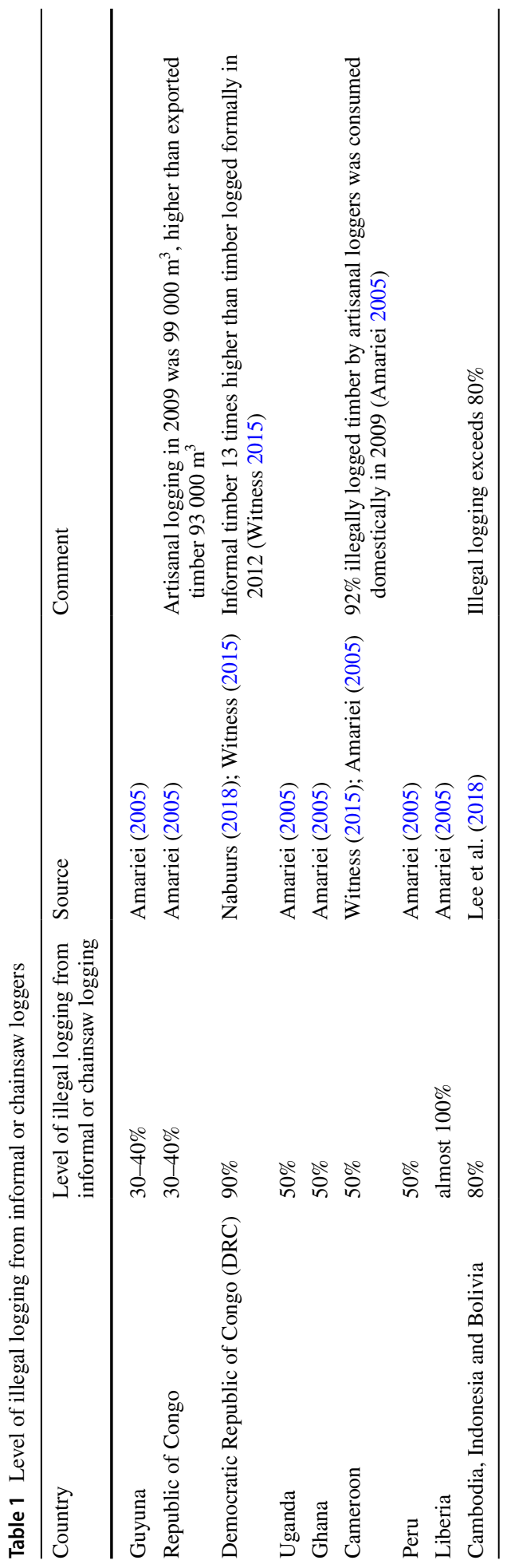


countries. However, the prevalence is higher amongst Congo Basin countries. Government officials are bribed during bidding for allocation of logging permits, during harvesting, forest controllers are bribed to overlook non-respect of logging areas, during transportation, transport documents are fortified, and road control officials are paid off to overlook; during sales, inspectors are bribed to overlook the sale of illegal timber or protected species (Lawson 2014). This phenomenon underlines the presence of a corruption chain within these countries, thus making it difficult for government policies and laws to be effectively applied due to vested interest from different actors along the chain. In Indonesia, the fall of president Suharto coupled with periods of political transition weakened the government, setting the pace for collusive corruption, thus high levels of illegal logging (Arias et al. 2013).

Empirical evidence from 117 countries between 1990 and 2000 shows that countries with higher levels of corruption are faced with higher levels of deforestation (Cerutti et al. 2013). Using forest conservation and a smaller number of countries, COHEN, M.A. 1999, equally concludes that protected areas are better managed in countries with low levels of corruption. Meyer et al. 2003 underscore that there is a strong positive correlation between high levels of illegal logging, deforestation and corruption. In Africa, Asia and Latin America. Wright et al. 2007 reported that high levels of corruption are associated with illegal forest conversion to agriculture and illegal logging. Alesina and Gennaioli (2014) highlight that officials allow rosewood to be cut in large quantities using false documents in return for bribe. Similar reports of illegal logging associated with corruption have been reported in Indonesia, Congo Basin and Latin America (Barbier et al. 2005; Gore et al. 2013). Poor instruments, weak institutional set-ups and ineffective forest agencies have been advanced as reasons for poor detection, and enforcement of forest activities (Milledge et al. 2007). In addition, countries with well-defined regulatory frameworks often suffer from financial and human resources to adequately enforce regulation (Milledge et al. 2007; Jakarta. 2011). Accentuate that up-to $40 \%$ and $69 \%$ of baseline timbers from state and federal undesignated lands of Amazonia, respectively, are subject to illegal logging. Thus, defining clear regulation on land ownership and enforcement of regulation can help curb illegal logging. The varying levels of corruption have different effects on tree cover, deforestation levels and carbon sequestration potentials of different land uses and thus impacts on carbon emission. Using satellite imagery, Wright et al. (2007) reported that protected areas are better managed in countries with lower levels of corruption. Contrary to popular knowledge, Wendland et al. (2014) highlighted that increased levels of good governance in Eastern Russia correlates with high rates of deforestation and illegal logging. CisnerosMontemayor et al. (2013) equally reported that municipalities with constant corruption audits in Brazil witnessed increased deforestation and illegal logging compared to municipalities with less control.

\section{Material and methods}

\subsection{Data sources}

Time series data ranging from 2000-2016 from three datasets are used in this paper. Governance-related variables such as corruption and government effectiveness were extracted from the World Governance Indicators database (2019). These variables permitted the estimation of the level of corruption, how it contributes to illegal logging, government 
effectiveness which captures perceptions of the quality of public services, the civil service quality and the degree of its independence from political pressures, policy formulation, implementation policy and the credibility of the government's commitment to such policies. Estimate gives the country's score on the aggregate indicator, in units of a standard normal distribution, i.e. ranging from approximately -2.5 to 2.5 . Other control variables such as arable land which captures the rate of deforestation for agricultural purpose and rural population which captures the pressure on land in rural areas or adjacent forest areas are extracted from the World Development indicators (2019). Carbon emission is captured using $\mathrm{CO}_{2}$ emissions from other sectors, not including emissions from residential buildings and commercial and public services, but contains emissions from commercial/institutional activities, residential, agriculture/forestry, fishing and different emissions not specified elsewhere that are included in the IPCC Source/Sink Categories $1 \mathrm{~A}_{4}$ and $1 \mathrm{~A}_{5} \mathrm{~s}$ also extracted from the World Development Indicator. Data on illegal logging were extracted from the Chatham house database. Six timber-producing countries based on data availability make up the sample, three from the Congo Basin (Democratic Republic of Congo, Congo Republic, Cameroon) and three Asian countries (Indonesia, Laos, Malaysia). Data on illegal logging are not always easy to find or estimate; the section below highlights data quality issues and actions taken to ensure the best quality data is used.

\subsection{Illegal logging data quality issues}

Due to the nature of the logging activity, it is difficult to comprehensively estimate or evaluate the level of illegal logging at the global or regional scale (European Union 2002; FAO 2001). Kaimowitz (2003) underscores that most of the information is speculative. Estimating illegal logging directly is very difficult or impossible since actors do all to erase traceability. Differences in definition of illegal logging by country and organization equally make quantification difficult (World Bank 2009). Different indirect methods have been developed to estimate the amplitude of illegal logging over time. Trade data discrepancies, import source analysis, wood balance analysis, expert surveys and hybrid analysis emerge amongst the most common methods used for estimating illegal logging. Most of these methods have dwelled on illegal production and international trade of timber (Nabuurs 2018). Other studies have employed more than one method; this permits the authors to have a better appreciation of the extent of illegal logging. Wood flow analysis (import source) coupled with interviews in producing countries was used by (Brack and Hayman 2001). Chatham house database on illegal logging uses a variety of methods amongst which are wood balance analysis, expert surveys and other related methods. Attempts have been made to estimate illegal logging from forest conversion for agricultural activities (crop and livestock) and associated trade (World Bank 2002). System dynamics models have emerged as an interesting method to estimate illegal logging over time (Kaimowitz 2003). This is because it permits the construction of stocks and flow of information from different datasets linked through intermediary functions and data structures (Vézina 2015). This method assumes that the total legal wood harvest from forestland is different from total wood supply in the state, the gap is illegally logged timber. Chatham house dataset on illegal logging was used in this paper for two principal reasons; (1) due to high discrepancies in different methodologies; Chatham house uses a combination of different methods to reduce estimation errors to the minimum. Trade discrepancies, wood balance analysis, analysis of trade for both importing and exporting countries and expert perception survey on the scale of illegal logging were used to determine levels of illegal logging and trade. (2) The application of 
Table 2 Averages of key variables over the study period

\begin{tabular}{lllcll}
\hline Region & Country & $\begin{array}{l}\text { Illegal logging }(\% \\
\text { from illegal origins) }\end{array}$ & Carbon emissions (kt) & $\begin{array}{c}\text { Corruption } \\
\text { estimate }\end{array}$ & $\begin{array}{c}\text { Government } \\
\text { effectiveness }\end{array}$ \\
\hline $\begin{array}{l}\text { Congo } \\
\text { Basin } \\
\text { countries }\end{array}$ & Cameroon & 32 & 5371.45 & -1.11 & -1.11 \\
& Congo Republic & 66 & 2109.15 & -1.13 & -1.19 \\
& $\begin{array}{l}\text { Democratic } \\
\text { Republic of }\end{array}$ & 47 & 1781.25 & -1.38 & -1.63 \\
& Congo & & & & \\
$\begin{array}{c}\text { Asian } \\
\text { timber- } \\
\text { producing } \\
\text { countries }\end{array}$ & Indonesia & 46 & $425,780.43$ & -0.72 & -0.27 \\
\hline
\end{tabular}

a common methodology in different countries allows for multi-country analysis. Table 2 underscores averages of key variables for the sampled countries over the study period.

Table 2 shows averagely higher levels of illegal logging amongst Congo Basin timberproducing countries compared to Asian timber-producing countries. In the Congo Basin, Cameroon averages 32\%, 66\% of timber traded from Congo Republic is from illegal sources, while an average of $47 \%$ is reported for DRC. These countries also exhibit poor governance ratings; this is captured by scores for corruption and governance effectiveness of -1.1 and below. Except for Indonesia with an average of $46 \%$, the other timber-producing countries show relatively lower levels of timber traded with high risk of illegality; these countries also portray better governance scores compared to Congo Basin countries. Analysis in this paper was done separately so as to underscore how differences in levels of illegal logging and governance between the two regions affect carbon emission.

\subsection{Data analysis}

This paper seeks to empirically investigate the effect of illegal logging and governance effectiveness on carbon emission and verify whether there is any long-run association between illegal logging, governance effectiveness and carbon emission within the Congo Basin and Asian timber-producing countries. Panel dynamic co-integrated regression model (DOLS) was used in this paper because it efficiently estimates the long-run relationship between variables within a macro-time series framework. Empirical evidence highlights that asymptotic properties of regression coefficients and corresponding statistical tests are different from time series co-integration regression models (Hsiao et al. 1995; Chen et al. 1999; Kao and Chiang 2000). Dynamic ordinary least square (DOLS) is more appropriate to other estimation techniques such as ordinary least square (OLS) and fully modified OLS (FMOLS); they generally improve the OLS estimator significantly (Gilbert and Troitzsch 1999). Hsiao et al. 1995 added the fully modified OLS (FMOLS) and OLS both show signs of small sample bias; thus, dynamic OLS (DOLS) estimator outperforms both estimators. E-views 10 software was used to construct a panel data structure because it allows for both inter-individual and intra-individual dynamics analysis. That is, it combines both cross section and times series data which contains higher degree of freedom and thus produces more robust results (Musango et al. 2012). The panel data framework also permits an evaluation of the long-run relationship between carbon emission, illegal logging and governance effectiveness; it equally allows to test for co-integration. 
Investigating whether the probability distribution function of a time series change over time is imperative for time series analysis, the presence of unit roots was used to check whether a time series is stationary or not using the augmented Dickey-Fuller test (ADF) developed by (Phillips and Moon 1999). Johansen's procedure is often used to test for the existence of a long-run relationship; however, within a multivariate system, with small sample the results can be distorted. Within a panel structure with time series and cross section data, several tests proposed by (Pedroni 2000; Im et al. 2003) were used; they test the null hypothesis of no co-integration against an alternative hypothesis of co-integration. Testing panel co-integration between variables should allow for as much heterogeneity between individual countries of the panel as possible. When results rely on the theory of homogeneous panel co-integration, a common slope coefficients imposes. Kao 1999 underscores that when common estimator is used when there are differences among individual countries; then the variables cannot be co-integrated. Pedroni 1999 residual test was used because it allows the identification of country specific differences, it contains seven tests: four for within-dimension panel and three for betweendimension group, and the weighted statistics are highlighted in the within-dimension panel tests.

\section{Results and discussion}

For the results of the regression analysis to be valid and robust, the assumptions for asymptotic analysis must be valid; this requires the test for unit root. Table 3 shows the results of the Dickey-Fuller unit root test for timber-producing countries in the Congo Basin and Asia. The results show that all the variables become stationary after first difference, suggesting that the use of a co-integrating regression analysis is most

Table 3 Augmented Dickey Fuller unit root test

\begin{tabular}{|c|c|c|c|c|c|}
\hline \multirow{3}{*}{$\begin{array}{l}\text { Congo Basin timber-pro- } \\
\text { ducing countries }\end{array}$} & \multicolumn{4}{|c|}{ Augmented Dickey-Fuller test } & \multirow[t]{3}{*}{ Decision } \\
\hline & \multicolumn{2}{|l|}{ Level } & \multicolumn{2}{|l|}{ First difference } & \\
\hline & Trend \& inter & Probability & trend and inter & Probability & \\
\hline Carbon emission $\left(\mathrm{CO}_{2}\right)$ & 11.7536 & 0.0677 & 26.5595 & 0.0002 & $\mathrm{I}(1)$ \\
\hline Illegal logging & 3.06231 & 0.8010 & 14.3330 & 0.0261 & $\mathrm{I}(1)$ \\
\hline corruption & 13.0350 & 0.0525 & 15.7600 & 0.0151 & $\mathrm{I}(1)$ \\
\hline Government effectiveness & 8.25981 & 0.2197 & 13.2290 & 0.0395 & $\mathrm{I}(1)$ \\
\hline Rural population & 10.9533 & 0.0542 & 23.0361 & 0.0008 & $\mathrm{I}(1)$ \\
\hline Arable land & 3.65373 & 0.7234 & 31.4943 & 0.0000 & $\mathrm{I}(1)$ \\
\hline \multicolumn{6}{|c|}{ Asian timber-producing countries } \\
\hline Carbon emission $\left(\mathrm{CO}_{2}\right)$ & 11.1207 & 0.0847 & 15.4087 & 0.0173 & $\mathrm{I}(1)$ \\
\hline Illegal logging & 5.12669 & 0.5277 & 17.6569 & 0.0071 & $\mathrm{I}(1)$ \\
\hline corruption & 4.52449 & 0.9206 & 28.1659 & 0.0017 & $\mathrm{I}(1)$ \\
\hline Government effectiveness & 9.8278 & 0.0716 & 20.0981 & 0.0027 & $\mathrm{I}(1)$ \\
\hline Rural population & 10.9555 & 0.0542 & 43.6132 & 0.0000 & $\mathrm{I}(1)$ \\
\hline Arable land & 10.8391 & 0.0515 & 28.1397 & 0.0001 & $\mathrm{I}(1)$ \\
\hline
\end{tabular}

Source: Author analysis 
appropriate. However, it is good to further test for co-integration using the Pedroni residual co-integration test.Source: Author analysis

\subsection{Pedroni co-integration test results}

Results of the test for the existence of a long-run relationship between illegal logging and carbon emission are shown in Table 4 for 11 within- panel and between-dimension tests for both Congo Basin and Asian timber-producing countries. Six of the 11 test results are significant for both Congo Basin and Asian timber-producing countries. This suggests that trends in illegal logging and carbon emission under normal circumstances will continue and will converge at one point in the long-run.

The existence of co-integration between the variables suggests that co-integration regression models are best suited for analysis of the impact of illegal logging on carbon emission. Dynamic ordinary least square regression was used, and Table 5 highlights the results of the regression.

\subsection{Dynamic ordinary least square regression results}

The results of the DOLS regression for Congo Basin and Asian timber-producing countries are highlighted in Table 5. This table shows that globally for both regression models the explicative power of the model is high. The respective adjusted R-squares of $99.3 \%$ and $97.4 \%$ of the variance of carbon emission $\left(\mathrm{CO}_{2}\right)$ are explained by independent variables used in the model for both Congo Basin and Asian timber-producing countries, meaning the regression models are globally robust and explicative enough.

The regression results above show that there is a positive and significant impact of illegal logging on carbon emission in the Congo Basin timber-producing countries. A unit change in illegal logging increases $\mathrm{CO}_{2}$ emission by 0.15 units; this is statistically significant at $1 \%$ level. As for Asian timber-producing countries, there is a positive but not significant impact; the magnitude of the slope of illegal logging is equally low (0.0657), while the impact of illegal logging on carbon emission is not significant. This suggests that illegal logging impacts on carbon emission are higher in Congo Basin timber-producing countries than in Asian timber-producing countries. This confirms the results of the trend analysis where trend of illegal logging is reducing in Asian timberproducing countries and increasing within Congo Basin timber-producing countries. The repercussions of illegal logging can be classified into economic, environmental and social. However, the environmental effects seem to be gaining significant grounds in the literature due to the adverse effects of carbon emission. The results in this paper show that high levels of illegal logging lead to increase in carbon emission. Pearson et al. (2017a) estimated that 53\% of annual carbon emission from 74 developing countries is related to timber exploitation, and carbon emission mitigation can be significantly enhanced by reducing illegal logging in timber-producing countries. However, for this to happen it is important to understand who the major actors are and what drives illegal logging within these countries. The composition of the increasing trend of illegal logging in the Congo Basin is highly debated (Nabuurs 2018; Cerutti and Lescuyer 2011; Lescuyer et al. 2014; Siebock 2002).

Corruption which is considered as an important governance indicator has a positive and significant impact on carbon emission within Congo Basin producing countries. A unit 


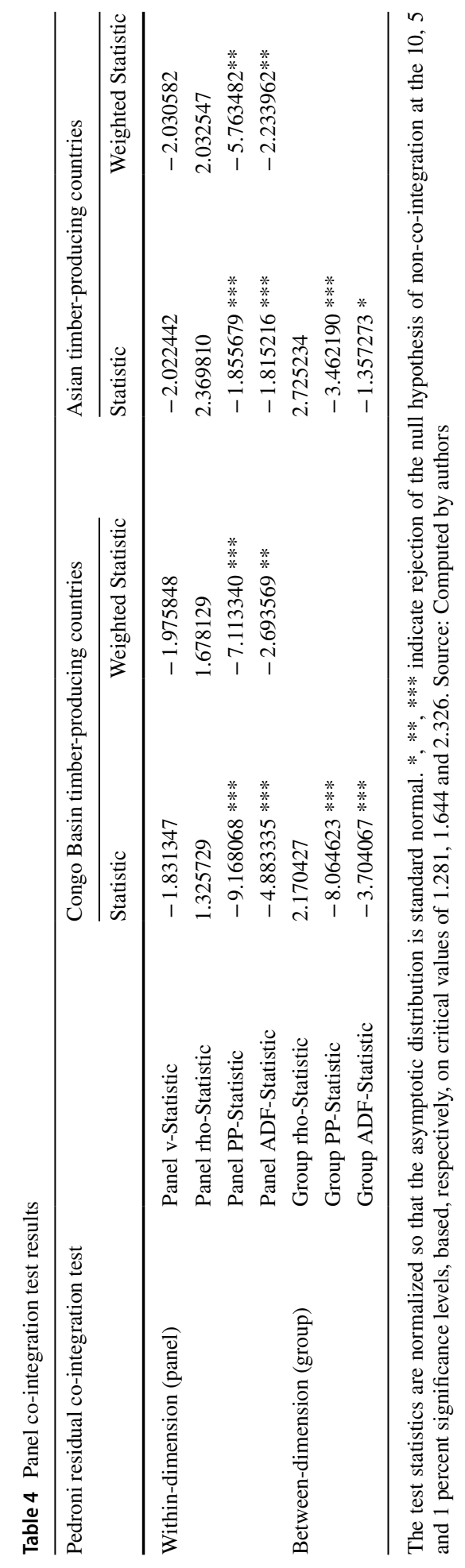


Table 5 DOLs regression for Congo Basin and Asian timber-producing countries

\begin{tabular}{|c|c|c|c|c|c|c|}
\hline \multirow[t]{2}{*}{ Carbon emission $\left(\mathrm{CO}_{2}\right)$} & \multicolumn{3}{|c|}{$\begin{array}{l}\text { Congo Basin timber-producing } \\
\text { countries }\end{array}$} & \multicolumn{3}{|c|}{ Asian timber-producing countries } \\
\hline & Coefficient & Std. Error & Prob & Coefficient & Std. Error & Prob \\
\hline Corruption & 0.029892 & 0.013502 & 0.0352 & 0.054466 & 0.078523 & 0.4917 \\
\hline Government effectiveness & 0.031118 & 0.014980 & 0.0471 & -0.290957 & 0.099300 & 0.0055 \\
\hline Illegal logging & 0.149815 & 0.029409 & 0.0000 & 0.065791 & 0.114670 & 0.5692 \\
\hline Rural Pop & 0.001845 & 0.004087 & 0.6552 & -0.303687 & 0.100367 & 0.0042 \\
\hline Arable Land & -0.094285 & 0.034297 & 0.0103 & 0.013617 & 0.022518 & 0.5486 \\
\hline R-squared & 0.996535 & 0.978492 & & & & \\
\hline Adjusted R-squared & 0.993812 & 0.974395 & & & & \\
\hline Long-run variance & 0.00000 & 0.000980 & & & & \\
\hline
\end{tabular}

change in corruption index leads to an increase in $\mathrm{CO}_{2}$ emission by 0.03 units; this is statistically significant at $5 \%$ level. However, the impact of corruption on $\mathrm{CO}_{2}$ emission in Asian producing countries is positive but not significant. This means that corruption levels are significantly higher in Congo Basin timber-producing countries thus creating an enabling environment for illegal timber exploitation and its eventual impacts on carbon emission.

Government effectiveness, which captures the perceptions of the quality of public services, the quality of the civil service and the degree of its independence from political pressures, has a positive and significant impact on carbon emission in the Congo Basin area. The regression result illustrates that a unit change in government effectiveness increases $\mathrm{CO}_{2}$ emission by 0.03 units, this is statistically significant at $5 \%$ level. This means that due to the ability of the public service to succumb to political pressure, poor policy implementation and overall poor control mechanisms, Congo Basin countries find it difficult to effectively control and reduce illegal logging activities, which in turn contributes significantly to carbon emission. The situation amongst the Asian timber-producing countries is different; due to comparably more effective law enforcement system and a more credibly public sector, government effectiveness turns to have a negative and significant impact on carbon emission. This means that a unit change in government effectiveness reduces carbon emission by 0.29 units, this is statistically significant at $1 \%$ level. The results from this paper show a positive and significant impact of corruption and government effectiveness on carbon emission within Congo Basin countries. This means that high levels of corruption and poor government effectiveness in implementing laws and policies related to carbon emission lead to higher levels of carbon emission. Results show that for Asian timber-producing countries, there is a positive but not significant impact on carbon emission. Based on the results of this study and Pandya (2002), the prevalence of corruption and poor law enforcement is higher within Congo Basin countries than amongst Asian timber-producing countries. The role of governance in combatting or enabling illegal logging and subsequent impact on carbon emission reported in this paper is supported by the findings of Ranjan and Truong (2018) who underscored that corruption and decentralisation in Indonesia had a positive and significant impact on illegal logging. This also confirms the findings of Casson and Obidzinski, (2002) who showed that illegal logging is a complex political dynamic system in rural Indonesia.

The effect of rural population pressure on carbon emission in Congo Basin countries is different from that of Asian timber-producing countries. The results indicate that there 
is a positive but not significant impact of rural population on carbon emission in Congo Basin. This is principally because an increase in rural population comes with an increase in demand for farmland, thus the clearing of forestland which increases carbon emissions (Pedronoi 2007; Li et al. 2011). However, in the Asian producing countries, a unit change in rural population reduces carbon emission by 0.30 units; this is statistically significant at $1 \%$ level. In these countries, output per hectare is significantly higher and farmer knowledge on farm optimization is significantly advanced than in the Congo Basin; thus, pressure to clear new farmlands within the forest is significantly reduced.

The regression table above shows that arable land use does not increase carbon emission, but rather there is a negative and significant effect of arable agriculture on carbon emissions in the Congo Basin. A unit change in arable land area use reduces $\mathrm{CO}_{2}$ emission by 0.09 units. However, the use of forestland for arable farming contributes positively to carbon emission. Forest conversion to agriculture has equally been one of the principal drivers of illegal logging especially by small holder farmers ( $\mathrm{Li}$ et al. 2011). Land conversion for plantations in Indonesia remains high; this explains the positive but not significant effect of arable land on carbon emission (Ahmed et al. 2016).

\section{Discussion of results}

\section{What explains the reducing trend and impact of illegal logging on carbon emission amongst Asia timber-producing countries?}

Although high, trends in illegal logging have been reducing amongst timber-producing countries in Asia except for Malaysia. Good forest governance has been highly promoted as a solution to the twin problem of corruption and illegal logging amongst timber-producing countries. Timber-producing, processing and consumer countries have taken several joint measures to combat illegal logging; however, the level of implementation varies from one country to another. Countries involved in the production and trade of timber have been working hard to curb illegal logging. Asian timber-producing countries, American and European countries agreed in 2001 to work together to curb illegal logging by adopting 50 actions at the national level and 20 regional actions (Godar et al. 2014). Since 2001, efforts in combating illegal logging have been outstanding in Indonesia, the first country to issue FLEGT licence through VPA. After 18 months of effective implementation of FLEGT, more than 40000 shipments of legal timber have been exported to the EU with over 39000 licences issued in 2018 alone (Margono et al. 2014). The success of Indonesia in putting in place an efficient timber verification system and FLEGT licensing system stems from the integrated approach employed by the state. This involves engagement of all stakeholders, decentralization of verification and certification to private sector with strong civil society monitoring that installs transparency (Sizer 2001). However, the increasing trend of illegal logging in Malaysia can be explained by internal differences within the Malaysian federation on the VPA, thus making it difficult for the country to make progress in implementing FLEGT (Sizer 2001).

Although enforcement of laws and policies aimed at reducing illegal logging remains one of the major huddles, implementation in other countries has improved significantly through capacity building of the different stakeholders and enforcement partners (FLEGT 2015). In Ghana, public prosecutors have been trained, a rapid response team and significant investment made to facilitate the use of information gathering tools. In Cameroon, 
prosecutors, ministry staffs and custom officials have been trained. However, low salaries and staff turnover have reduced the impact of these trainings (Hugh et al. 2012).

Collaboration between different stakeholders and countries is extremely important in reducing illegal logging and its subsequent incidence on carbon emission. Complex crimes require a multidisciplinary approach in tackling them and illegal logging is one of them (Huwart and Verdier 2013). Brazil's inter-ministerial commission against environmental crimes established in 2008, with law enforcement agencies, government environmental and intelligence agencies working hand in hand to curb illegal logging (Wells et al. 2006; Goncalves et al. 2012), remains a good example. This multidisciplinary team contributed significantly in enforcing environmental law and reducing illegal logging in Brazil (Spapens et al. 2016). Other aspects of collaboration being implemented in Cameroon and Republic of Congo between the government and independent monitoring agencies have contributed to reducing illegal logging. However, the global effect has not been significant because of limited power to monitor logging companies coupled with limited financial and human resources(Elliot and Schaedla 2016).

How can FLEGT and REDD + enhance forest governance and reduce illegal logging within the Congo Basin and Asia?

Timber-producing countries have been taking measures to tackle illegal logging, and trade, VPA negotiations and licencing have been prominent amongst actions being taken. So far, 05 African countries are leading the way in signing voluntary partnership agreements (VPA) with the EU; while only 02 countries have signed the VPA in Asia, 08 additional countries are currently negotiating the VPA with the EU. In Africa, Ghana started negotiations in March 2007 and signed the VPA in September 2013. Cameroon started negotiations in November 2007, signed VPA in October 2010, Central African Republic started negotiations in October 2008, signed VPA in November 2011, Congo stated negotiations in June 2008 and signed VPA on May 2010, while Liberia started negotiations on March 2011 and signed the VPA in July 2011. An average period of two years of negotiations is used by African countries. However, since signing the VPA, putting in processes for effective implementation of the FLEGT licencing system has already taken over five years for all African countries. Although many African countries signed the VPA agreement before any Asian country, Indonesia recorded significant progress in implementation after signing the VPA in 2013 becoming the first country to get the FLEGT timber export licence in 2015. This therefore means that the political will and processes put in place to ensure legality of timber is very important, which may explain the significant reduction of illegal logging in Indonesia in recent years. This equally explains why an institutional variable like government effectiveness portrays a negative and significant impact on carbon emission, because the political class puts in efforts to enforce good governance through law enforcement to combat illegal logging and carbon emission. However, the FLEGT-VPA process in many countries ensures legality of timber meant for export markets; timber destined for domestic markets is not considered. The domestic market for timber within Congo Basin countries is dominated by timber from artisanal loggers, most of which remains illegal (Witness 2015).

Timber-producing countries are equally engaged in REDD + programs aimed at reducing emissions due to deforestation and forest degradation. One important mechanism to tackle illegal logging is for these countries to accommodate both initiatives. Timber-producing countries can therefore explore possibilities of synergies between both initiatives to combat illegal logging. With the prominence of artisanal loggers within Congo Basin producing countries, REDD + payments can be used as incentives for artisanal loggers who respect FLEGT-VPA process for artisanal logging. 


\section{Conclusion and policy recommendations}

The relationship between governance and illegal logging is well established and debated in the literature; a majority of scientists underscore that illegal logging prevails when governance effectiveness is poor. However, a small group of researchers assert that illegal logging does not necessarily prevail due to poor governance. This paper extends the debate and contributes to scientific literature by (i) investigating the relationship between illegal logging and governance using time series data and econometric techniques and (ii) investigating the combined effect of illegal logging and governance on carbon emission. (iii) The paper targets countries that account for more than $50 \%$ of timber trade and illegally logged timber; thus, policy implications aimed at curbing illegal logging from these countries can significantly reduce global rates of illegal logging. There is a positive and significant impact of illegal logging and governance effectiveness on carbon emission amongst timber-producing countries in the Congo Basin. This suggests that a unit change in illegal logging or governance effectiveness increases carbon emission. This can be explained by the increasing trend of illegal logging and high levels of corruption, which is associated with illegal reduction of trees, thus reducing the sequestration potential of the forest and thus carbon emission. However, timber-producing countries in Asia show a slightly different scenario. The impact of illegal logging on carbon emission is positive but not significant; meanwhile, there is a negative and significant impact of governance effectiveness on carbon emission. This underscores the important role of recent efforts by governments of these countries in enhancing good governance and sustainable natural resource management. Due to more efficient governance effectiveness, changes in governance effectiveness turn to reduce impact on carbon emission, thus enhancing control of illegal logging.

Illegal logging by small-scale loggers and collusive corruption has been identified as some of the principal actors and mechanisms for facilitating trade in illegally logged wood, coupled with poor institutional framework for enforcement of laws and policy. This therefore underlines the fact that the prevalence of illegal logging is due to the porosity of the institutional framework for enforcement of forest laws and governance. With experiences of proper law enforcement through training, multidisciplinary approach, engagement of public-private sector in FLEGT implementation in Brazil, Indonesia and other Asian countries, there is hope that Congo Basin countries can still succeed in reducing illegal logging through a concerted approach. It is equally hoped that countries in the Congo Basin can reduce the rate of illegal logging if the following recommendations are applied:

- Multidisciplinary approach should be used, engaging the timber concessions, governments and importing countries. Congo Basin countries should educate policy makers and develop processes and procedures for legality verification not only for large concessionaries but equally for smallholder loggers. The implementation of the FLEGT process should address context specific drivers of illegal logging and trade. Synergy between REDD + and FLEGT-VPA process should be enhanced to incentivise artisanal loggers to engage into formal timber exploitation with efficient timber traceability and legality.

- Deforestation due to illegal logging can be reduced if countries adopt smart agricultural practices with agroforestry at the centre of agricultural interventions. It increases yield per ha, increases soil fertility, permits the farmer to farm on the same piece of land for many years, reduces forest expansion for farmland and thus reduces illegal logging and deforestation, thus reducing carbon emissions. 
- Cost and procedures for obtaining logging licence by small loggers should be reduced such that these loggers see a substantial financial gain in moving from the informal sector to the formal sector. Effective training of stakeholders related to enforcement of laws and policies related to combating illegal logging and carbon emission should be done at scale.

Acknowledgements The authors of this paper will like to thank the staff and friends of the World Agroforestry Centre

Author contributions SMP designed the study, wrote first draft and reviewed and submitted. TJC :Supervision, Writing - review \& editing, PAM: Supervision, Writing - review \& editing, DFT: Supervision, Writing - review \& editing, FN:Validation, Visualization

Funding The authors thank the landscape governance theme of ICRAF for the support.

Data availability Data for this study were extracted from the World Bank Development Indicator database, World Governance indicators and the Chatham house database that can be provided upon request.

\section{Compliance with ethical standards}

Conflict of interests The authors declare that they have no competing interests.

Consent to participate Not Applicable.

Ethics approval Not Applicable.

Open Access This article is licensed under a Creative Commons Attribution 4.0 International License, which permits use, sharing, adaptation, distribution and reproduction in any medium or format, as long as you give appropriate credit to the original author(s) and the source, provide a link to the Creative Commons licence, and indicate if changes were made. The images or other third party material in this article are included in the article's Creative Commons licence, unless indicated otherwise in a credit line to the material. If material is not included in the article's Creative Commons licence and your intended use is not permitted by statutory regulation or exceeds the permitted use, you will need to obtain permission directly from the copyright holder. To view a copy of this licence, visit http://creativecommons.org/licenses/by/4.0/.

\section{References}

Ahmed, K. F., Wang, G., You, L., \& Yu, M. (2016). Potential impact of climate and socioeconomic changes on future agricultural land use in West Africa. Earth System Dynamics, 7, 151-165.

Akindele, S. T. (2005). A critical analysis of corruption and its problems in Nigeria. Anthropologist, 7(1), $7-18$.

Alemagi, D., \& Kozak, R. A. (2010). Illegal logging in Cameroon: Causes and the path forward. Forest Policy and Economics, 12(8), 554-561. https://doi.org/10.1016/j.forpol.2010.07.008.

Alesina, A. C. Gennaioli, S. Lovo. (2014). Public goods and ethnic diversity: Evidence from deforestation in Indonesia. NBER Working Paper 20504.

Amaral, M. R. M., Lima, A. J. N., Higuchi, F. G., dos Santos, J., \& Higuchi, N. (2019). Dynamics of tropical forest twenty-five years after experimental logging in central amazon mature forest. Forests, 10, 89.

Amariei, L. (2005). Legal compliance in the forest sector: a case study of Cameroon. FAO, Rome: Final report.

Amazon. Forest Ecology and Management 157, 131-141.

Arias, P., Hallam, D., Krivonos, E., \& Morrison, J. (2013). Smallholder integration in changing food markets. Rome: Food and Agriculture Organization of the United Nations. 
Averchenkova, A., (2017) Engaging Private Sector and Mobilizing Private Finance through Mitigation Actions in Developing Countries. In: Markandya A, Galarraga I and Ruebbelke D (eds.) Climate Finance: Theory and Practice, pp. 55-78. World Scientific. DOI: https://doi.org/10.1142/9789814641 814_0004.

Baccini, W., Walker, L., Carvalho, M., Farina, D.-M., Houghton Erb, R. A., et al. (2017). Tropical forests are a net carbon source based on aboveground measurements of gain and loss. Science, 358(6360), 230-234. https://doi.org/10.1126/science.aam5962originallypublishedonlineSeptember28,2017.

Barbier, E. B., Damania, R., \& Leonard, D. (2005). Corruption, trade and resource conservation. Journal of Environmental Economics and Management, 50, 276-299.

Bisschop, L., 2015. Governance of the Illegal in e-Waste and Tropical Timber. Case studies on Transnational Environmental Crime. London: Routledge.

Brack, D., G. Hsayman, 2001. Intergovernmental actions on illegal logging: options for intergovernmental action to help combat illegal logging and illegal trade in timber and forest products, The Royal Institute of International Affairs, March 2001, 28 p.

Brown, D. \& Luttrell, C. 2004. Review of independent forest monitoring. London, UK, Overseas Development Institute (ODI) for DFID. Available at: www.odifpeg.org.uk/publications/reports/IFM\%20Pap er/IFMFinal.pdf

Carodenuto, S., \& Cerruti, P. O. (2014). Forest law enforcement, governance and trade (FLEGT) in Cameroon: Perceived private sector benefits from VPA implementation. Forest Policy and Economics, 48, $55-62$.

Cashore, B., 2009. Key components of good forest governance. ASEAN forests clearing house mechanism, ASEAN secretariat, Jakarta. http://www.aseanforest-chm.org

Cerutti, P.O., Lescuyer, G., 2011. The Domestic Market for Small-Scale Chainsaw Milling in Cameroon: Present Situation, Opportunities and Challenges. CIFOR, Bogor (Indonesia) (52 pp. Available online: http://www.cifor.org/publications/pdf_files/OccPapers/OP-61. pdf; accessed on December 14th, 2019).

Cerutti, P. O., Tacconi, T., Lescuyer, G., \& Nasi, R. (2013). Cameroon's hidden harvest: Commercial chainsaw logging, corruption and livelihoods. Society \& Natural Resources, 26, 539-553.

Chaudhary, A., Burivalova, Z., Koh, L. P., \& Hellweg, S. (2016). Impact of forest management on species richness: Global meta-analysis and economic trade-offs. Scientific Reports, 6, 23954.

Chen, B., McCoskey, S., \& Kao, C. (1999). Estimation and inference of a cointegrated regression in panel data: A Monte Carlo study. American Journal of Mathematical and Management Sciences, 19, 75-114.

Cisneros-Montemayor, A. M., Cisneros-Mata, M. A., Harper, S., \& Pauly, D. (2013). Extent and implications of IUU catch in Mexico's marine fisheries. Marine Policy, 39, 283-288. https://doi. org/10.1016/j.marpol.2012.12.003.

CITES, 2016. Convention on international trade in endangered and rare species of Wild Fauna and Flora. Available at: https://cites.org/. Accessed 18 June 2019.

COHEN, M.A. . (1999). Monitoring and enforcement of environmental policy. In T. Tietenberg \& H. Folmer (Eds.), International Yearbook of Environmental and Resource Economics, 3. UK: Edward Elgar Publishers.

Colchester, M., Boscolo, M., Contreras-Hermosilla, A., Del Gatto, F., Dempsey, J., Lescuyer, G., et al. (2006). Justice in the forest: Rural livelihoods and forest law enforcement. Center for International Forestry Research: Bogor.

DeFries, R. S., et al. (2002). Carbon emissions from tropical deforestation and regrowth based on satellite observations for the 1980s and 1990s. Proceedings of the National academy of Sciences of the United States of America, 99, 14256-14261.

Denman, K. L., Brasseur, G., Chidthaisong, A., Ciais, P., Cox, P. M., Dickinson, R. E., Hauglustaine, D., Heinze, C., Holland, E., Jacob, D., Lohmann, U., Ramachandran, S., Dias, P. L. d. S., Wofsy, S. C., and Zhang, X. (2007) Couplings between changes in the climate system and biogeochemistry., in: Carbon emission 2007: The physical science basis. Contribution of working group I to the fourth assessment report of the intergovernmental panel on carbon emission. In: Solomon, S., Qin, D., Manning, M., Chen, Z., Marquis, M., Averyt, K. B., Tignor, M., and Miller, H. L. (Eds.) Cambridge University Press, Cambridge, United Kingdom and New York, NY, USA, 500-587, Cambridge University Press.

Djiré A. (2003) Le secteur informel du bois d'oeuvre. Rapport d'appui à la revue du secteur forestier en RD Congo - Rapport technique. Montpellier, France, Centre de Coopération Internationale en Recherche Agronomique pour le Développement (CIRAD).

Edwards, F. A., Edwards, D. P., Hamer, K. C., \& Davies, R. G. (2013). Impacts of logging and conversion of rainforest to oil palm on the functional diversity of birds in Sundaland. Ibis, 155, 313-326. 
Edwards, F. A., Edwards, D. P., Larsen, T. H., Hsu, W. W., Benedick, S., Chung, A., \& Hamer, K. C. (2014). Does logging and forest conversion to oil palm agriculture alter functional diversity in a biodiversity hotspot? Animal Conservation, 17, 163-173.

Elliot, L., \& Schaedla, W. H. (2016). Handbook of transnational environmental crime (pp. 168-189). Cheltendam: Edward Elgar.

Environmental Investigation Agency, Inc. (2019). Toxic trade: Forest crimes in Gabon and the Republic of Congo and the contamination of the US market.

EUROPEAN COMMISSION. (2002). "European Commission stresses commitment to combat illegal logging”, Press release, IP/02/1254, August 31, 2002.

FAO: Global Forest Resources Assessment 2015. How are the world's forests changing? Second edition. Rome (2016). FERN, 2013, Fern annual report April 2013-March 2014.

FAO. (2001). Illegal activities and corruption in the forestry sector. State of the World's Forests 2001 (pp. 88-101).

FERN, 2013. FERN annual report 2013. https://www.illegal-logging.info/content/fern-annual-report-2013 [Accessed on 18 November 2019].

FLEGT, 2015. Three years of FLEGT licensing: EU and Indonesia take stock of forest governance progress. http://www.flegt.org/news/content/viewItem/three-years-of-flegt-licensing-eu-and-indonesia-takestock-of-forest-governance-progress/03-12-2019/280. Accessed December 25 ${ }^{\text {th }}, 2019$.

Gan, J., Cerutti, P., Masiero, M., Pettenella, D., Andrighetto, N., Dawson, T., (2016). Quantifying illegal logging and related timber trade. Pages 37-61. In: Kleinschmidt D, Mansourian S, Wildburger C, Purret A (eds.). Illegal Logging and Related Timber Trade-Dimensions, Drivers, Impacts and Responses. A Global Scientific Rapid Response Assessment Report. IUFRO World Series Volume 35. Vienna.

Gerwing, J. J. (2002). Degradation of forests through logging and fire in the eastern Brazilian Amazon. Forest Ecology and Management, 157, 131-41.

Gibson, L., Lee, T. M., Koh, L. P., Brook, B. W., Gardner, T. A., Barlow, J., et al. (2011). Primary forests are irreplaceable for sustaining tropical biodiversity. Nature, 478, 378-381.

Gilbert, N., \& Troitzsch, K. (1999). Simulation for the social scientist. Buckingham, UK: Open University.

Global Witness, 2004. SIGIF Report. Global Witness, London, the United Kingdom. Halvorsen, K., 1992. Methodology for social science. Student literature, Lund, Sweden. Hamilton Resources and Consulting. (2008). Alternative tenure and enterprise models in ghana: A country-level study. Washington DC, USA: Rights and Resources Initiative Group.

Godar, J., Gardner, T. A., Tizado, E. J., \& Pacheco, P. (2014). Actor-specifc contributions to the deforestation slowdown in the Brazilian Amazon. Proceedings of the National Academy ofSciences of the United States of America, 111(43), 15591-15596.

Goncalves, P. M., Panjer, M., Greenberg, T. S., \& Magrath, W. B. (2012). Justice for forests: Improving criminal justice efforts to combat illegal logging. Washington DC: The World Bank.

Gore, M. L., Ratsimbazafy, J., \& Lute, M. L. (2013). Rethinking corruption in conservation crime: Insights from Madagascar. Conservation Letters, 6(6), 430-438.

Guertin, C. E. (2003). Illegal logging and illegal activities in the forestry sector: overview and possible issues for the UNECE Timber Committee and FAO European Forestry Commission (p. 12). Canada. p: Quebec Wood Export Bureau.

Hansen, C., et al. (2012). Revisiting illegal logging and the size of the domestic timber market: The case of Ghana. International Forestry Review, 14(1), 1-11.

Hoare, A. (2014), Illegal Logging and Related Trade: The Response in Ghana. A Chatham House Assessment. https://www.chathamhouse.org/sites/default/files/field/field_document/20141029I1 legalLoggingGhanaHoareFinal.pdf.

Hoare, A. (2015). Tackling Illegal Logging and the Related Trade: What progress and where Next? Chatham House, London. https://www.chathamhouse.org//node/18090.

Holly and Martin. (2007). Tropical deforestation and greenhouse gas emissions. Environmental Research Letters, 2, 045021. https://doi.org/10.1088/1748-9326/2/4/045021.

House, C. (2015). Tackling illegal logging and related trade: What progress and where next. London: The Royal Institute of International Affairs.

Hsiao, C., Mountain, D. C., \& Ho-Illman, K. (1995). Bayesian integration of end-use metering and conditional demand analysis. Journal of Business \& Economic Statistics, 13, 315-326.

Huwart, J. Y., \& Verdier, L. (2013). Economic globalisation: Origins and consequences, OECD Insights. Paris: OECD Publishing.

Im, K., Pesaran, M., \& Shin, Y. (2003). Testing for unit roots in heterogeneous panels. Journal of Economics, 115, 53-74. 
IPCC, 2000: Emissions scenarios: special report of the Intergovernmental Panel on Carbon emission 6 (IPCC). Nakicenovic, N., and R. Swart (eds.). Cambridge University Press: Cambridge, 570 pp.

IPCC Carbon emission 2014: Synthesis Report (eds Pachauri, R. K. \& Meyer, L. A.) (Cambridge Univ. Press, 2014).

Joseph, S., Rita, P., Wright, M., Rafique, M., \& Afzal, K. (2004). Landscapes, soils, and mound histories of the upper Indus Valley, Pakistan: New insights on the Holocene environments near ancient Harappa. Journal of Archaeological Science, 31(6), 777-797.

Kaimowitz, D. (2003). Forestry law enforcement and rural livelihoods. International Forestry Review, 5(3), 199-210.

Kao, C. (1999). Spurious regression and residual-based tests for cointegration in panel data. Journal of Econometrics, 90, 1-44.

Kao, C., \& Chiang, M.-H. (2000). On the estimation and inference of a cointegrated regression in panel data. In B. Baltagi (Ed.), Advances in Econometrics: Nonstationary panels, panel cointegration and dynamic panels (Vol. 15), pp. 179-222). London: Emerald Group Publishing Ltd.

Kishor, N., \& Lescuyer, G. (2012). Controlling illegal logging in domestic and international markets by harnessing multilevel governance opportunities. International Journal of the Commons, 6(2), 255-270.

Lawson, S. (2014), Methodology for Import-source Estimates of Illegally Sourced Wood Imports: Thailand, South Korea and India.

Lawson, S., \& MacFaul, L. (2010). Illegal logging and related trade: Indicators of the global response. London: Chatham. http://goo.gl/DFskg1. Accessed 7 Dec 2020.

Lee, J. H., Kubo, Y., Fujiwara, T., Septiana, R. M., Riyanto, S., \& Iwasa, Y. (2018). Profit sharing as a management strategy for a state-owned teak plantation at high risk for illegal logging. Ecological Economics, 149, 140-148. https://doi.org/10.1016/j.ecolecon.2018.03.005.

Lescuyer, G., Ndotit, S., Ndong, L.B.B., Tsanga, R. and Cerutti, P.O., 2014. Policy Options for Improved Integration of Domestic Timber Markets under the Voluntary Partnership Agreement (VPA) Regime in Gabon. CIFOR Infobrief No. 82. Bogor: Centre for International Research on Forestry (CIFOR).

Li, B., Fu, S. Y., Zhang, J. B., \& Yu, H. S. (2011). Carbon functions of agricultural land use and economy across China: A correlation analysis. Energy Procedia, 5, 1949-1956.

Lindner, M., Fitzgerald, J. B., Zimmermann, N. E., Reyer, C., Delzon, S., van der Maaten, E., et al. (2014). Carbon emission and European forests: What do we know, what are the uncertainties, and what are the implications for forest management? Journal of Environmental Management, 146, 69-83.

Marfo, E., 2010. Chainsaw milling in Ghana: Context, drivers and impacts. EFTRN News 52. http://hdl. handle.net/123456789/995.

Margono, B. A., Potapov, P. V., Turubanova, S., Stolle, F., \& Hansen, M. C. (2014). Primary forest cover loss in Indonesia over 2000-2012. Nature Clim. Change, 4, 730-735.

Meyer, A. L., van Kooten, G. C., \& Wang, S. (2003). Institutional, social and economic roots of deforestation: A cross-country comparison. International Forestry Review, 5, 29-37.

Milledge, S.A.H., I. K. Gelvas, Ahrends, A. (2007). Forestry, governance and national development: Lessons learned from a logging boom in Southern Tanzania. TRAFFIC East/Southern Africa/Tanzania Development Partners Group/Ministry of Natural Resources of Tourism, Dar es Salaam, Tanzania.

Moiseyev, A., Solberg, B., Michie, B., \& Kallio, A. M. I. (2010). Modelling the impacts of policy measures to prevent import of illegal wood and wood products. Forest Policy Econ, 12, 24-30.

Musango, J. K., Brent, A. C., Amigun, B., Pretorius, L., \& Muller, H. (2012). A systemdynamics, approach to technology sustainability assessment: the case of biodieseldevelopments in South Africa. Technovation, 32(11), 639-651.

Nabuurs, et al. (2018). Understanding the implications of the EU-LULUCF regulation for the wood supply from EU forests to the EU. Carbon Balance and Management. https://doi.org/10.1186/s1302 1-018-0107-3.

Nguyen, H. N., \& Cao, N. A. (2020). An alternative approach to classify illegal logging: The case in Vietnam. International Journal for Crime, Justice and Social Democracy, 9(3), 130-143. https://doi. org/10.5204/ijcjsd.v9i3.1336.

Pandya, J., 2002. Logging - a Sustainable Future in Cameroon? WWF Forest forLife Program. Manuscript available online at: http://www.wwf.or.th/about_wwf/where_we_work/africa/news/index.cfm?uNews $\mathrm{ID}=11521$

Pearson, N., Griffiths, P., Biddle, S. J., Johnston, J., \& Haycraft, E. (2017a). Individual, behavioural and home environmental factors associated with eating behaviours in young adolescents. Appetite, 112, 35-43.

Pearson, T., Brown, S., Murray, L., \& Sidman, G. (2017b). Greenhouse gas emissions from tropical forest degradation: An underestimated source. Carbon balance and management, 12(1), 3. 
Pedroni, P. (1997) Panel cointegration; asymptotic and finite sample properties of pooled time series tests, with an application to the PPP hypothesis: New results. Working paper, Indiana University.

Pedroni, P. (1999). Critical values for cointegration test in heterogeneous panels with multiple regressors. Oxford Bulletin of Economics and Statistics, 61, 653-670.

Pedroni, P. (2000). Fully-modified OLS for heterogeneous cointegrated panels. Advances in Econometrics, 15, 93-130.

Pesaran, M.H. and Y. Shin (1995), ìLong-Run Structural Modelling,î unpublished manuscript, University of Cambridge.

Phillips, P. C. B., \& Moon, H. R. (1999). ilLinear regression limit theory for nonstationary panel dataî. Econometrica, 67, 1057-1111.

Putz, F. E., \& Romero, C. (2014). Futures of tropical forests (sensu lato). Biotropica, 46(4), $495-505$.

Putz, F. E., Zuidema, P. A., Synnott, T., Peña-Claros, M., Pinard, M. A., Sheil, D., et al. (2012). Sustaining conservation values in selectively logged tropical forests: the attained and the attainable. Conservation Letters, 5(4), 296-303.

Puzon, K., Muttaqien, A., Song, X., \& Nguyen, D.T. (2011). A literature review on the log export ban policy in developing countries: From the perspective of environmental economics.

Ranjan, R., \& Truong, C. (2018). Determinants of illegal logging in Indonesia: An empirical analysis for the period 1996-2010. Journal of Sustainable Forestry, 37(2), 197-220. https://doi.org/10.1080/10549 811.2017.1369436.

Reboredo, F. (2013). Socio-economic, environmental, and governance impacts of illegal logging. Environment Systems \& Decisions, 33, 295-304. https://doi.org/10.1007/s10669-013-9444-7.

Richardson, M., Cowtan, K., Hawkins, E., \& Stolpe, M. B. (2016). Reconciled climate response estimates from climate models and the energy budget of Earth. Nature Climate Change, 6, 931-935.

RIIA (2003), Scale of illegal logging, http://illegal-logging.info/Scale.htm.

Santos de Lima, L., Merry, F., Soares-Filho, B., Oliveira Rodrigues, H., dos Santos Damaceno, C., \& Bauch, M. A. (2018). Illegal logging as a disincentive to the establishment of a sustainable forest sector in the Amazon. PLoS ONE, 13, 1-21.

Schrope, M. (2009). When money grows on trees. Nature Reports Carbon emission, 3, 101-103.

Seneca Creek Associates, 2004. Illegal logging and global wood markets: The competitive impacts on the U.S. wood products industry. Seneca Greek Associates. LLC. Poolesville, MD.

Siebock, G., 2002. A political, legal and economic framework for sustainable forest management in Cameroon: Concerted initiatives to save the rainforest. A thesis submitted in partial fulfillment of the requirement for the degree of masters in science (MSc) LUMES Lund University Masters in Environmental Science.

Sizer, N. C. (2001). Regional approaches to tackle illegal logging and associated trade in Asia. http://www. fao.org/3/y5841e/y5841e10.htm\#TopOfPage.

Smith, J., Obidzinski, K., \& Subarudi, S. I. (2003). Illegal logging, collusive corruption and fragmented governments in Kalimantan Indonesia. International Forestry Review, 5(3), 293-302.

Smith, P. et al. (2014), Agriculture, forestry and other land use (AFOLU), in intergovernmental panel on carbon emission (2014), carbon emission 2014: Mitigation of carbon emission. Contribution of working group III to the fifth assessment report of the intergovernmental panel on carbon emission. Cambridge: Cambridge University Press (at https://www.ipcc.ch/publications_and_data/publicatio ns_and_data_reports.shtml\#1).

SMITH, W. . (2002). The global problem of illegal logging. ITTO Tropical Forest Update, 10(1), 3-5.

Spapens, T., White, R. and Huisman, W., 2016. Introduction. In: Environmental Crime in Transnational Context. Global Issues in Green Enforcement and Criminology, edited by T. Spapens, R. White and W. Huisman. London: Routlegde, pp. 1-6.

Speechly hugh and helden, FLIP VAN 2012. Forest governance in Southeast Asia. ETFRN NEws 53: ApRil 2012.

Strasser, U., Vilsmaier, F., Prettenhaler, T., Marke, R., Steiger, A., Damm, F., \& hanzer R., Wilcke J. and Stötter J., . (2014). Coupled component modelling for inter- and transdisciplinary climatechange impact research: Dimensions of integration and examples of interface design. Environmental Modeling and Software, 60, 180-187.

Transparency International Indonesia. (2011). Forest governance integrity report. Indonesia. Technical report, Transparency International Indonesia: Jakarta.

UNODC. (2012). Transnational organized crime in central america and the caribbean: A threat assessment. Vienna, Austria: United Nations Office on Drug and Crime.

verchenkova, A., Gannon, K. E., Patrick, C., (2019) Governance of carbon emission policy: A case study of South Africa. London: Grantham Research Institute on Carbon emission and the Environment 
and Centre for Carbon emission Economics and Policy, London School of Economics and Political Science.

Vézina, P.-L. (2015). Illegal trade in natural resources: Evidence from missing exports. International Economics, CEPII research center, issue, 142, 152-160.

Wells, K. M., Pfeiffer, M. B., \& Lakim, E. K. V. (2006). Kalko Movement trajectories and habitat partitioning of small mammals in logged and unlogged rainforests in Borneo. Journal of Animal Ecology, 75, 1212-1223.

Wendland, K. J., Lewis, D. J., \& Alix-Garcia, J. (2014). The effect of decentralized governance on timber extraction in European Russia. Environmental and Resource Economics, 57(1), 19-40.

Wit, M., Van Dam, J., Cerutti, P. O., Lescuyer, G., Kerret, R., \& Parker McKeown, P. O. (2010). Chainsaw milling: Supplier to local markets - A synthesis. European Tropical Forest Research Network (ETFRN) News 52:vii-xxii.

Global Witness, 2015. Urgent action required to cut trade and aid ties to logging companies that have paid millions to militia guilty of mass murder and war crimes. https://www.globalwitness.org/en/campa igns/forests/bloodtimber/ accessed on December 25th, 2019.

World Bank, 2009. County Brief. World Bank, Washington DC, USA. Available online at:http://go.world bank.org/I7KMKA50S0.

WORLD BANK, 2002. A revised strategy for the World Bank Group, October 31, 48 p.

WORLD BANK. . (2006). Strengthening forest law enforcement and governance: Addressing a systematic constraint to sustainable development. Washington DC: The World Bank.

World Development Indicators (WDI). (2019). https://datatopics.worldbank.org/world-development-indic ators/.

Worldwide Governance Indicators (WGI). (2019). https://databank.worldbank.org/source/worldwide-gover nance-indicators.

Wright, S. S., Sanchez-Azofeifa, A., Portillo-Quintero, C., \& Davies, D. (2007). Poverty and corruption compromise tropical forest reserves. Ecological Applications, 17, 1259-1266.

Publisher's Note Springer Nature remains neutral with regard to jurisdictional claims in published maps and institutional affiliations. 